\title{
A new focus of the tick Haemaphysalis concinna in Western Poland
}

\author{
Dorota Dwużnik $^{1} \cdot$ Ewa J. Mierzejewska $^{1} \cdot$ Mohammed Alsarraf $^{1} \cdot$ Anna Bajer $^{1}$
}

Received: 7 February 2019 / Accepted: 7 May 2019 / Published online: 21 May 2019

(c) The Author(s) 2019

\begin{abstract}
The relict tick Haemaphysalis concinna has a fragmented and focal distribution in Central Europe and Asia. Although in the majority of neighboring countries the occurrence of this tick species is well-documented (i.e., in Germany, Czech Republic, Slovakia, Ukraine), todate its occurrence in Poland has been registered only once, in 1953 in Troszyn in NorthWestern Pomerania, close to the German-Polish border. In the present study we report the first documented finding of $H$. concinna in Western Poland, confirmed both by collection of juvenile ticks from rodent hosts and questing ticks from vegetation. Trapping of rodents took place in the summer of 2018 in three locations in Western Poland (Słonin, Nowy Młyn 1, Nowy Młyn 2). Rodents were inspected for ectoparasites, which were detached and fixed in $70 \%$ ethanol. All the collected ticks were assigned to species and developmental stages using appropriate morphological keys, and representative individuals were genotyped by molecular methods. A total of 1482 feeding ticks were collected from 106 rodents from three sites. The common tick Ixodes ricinus was found in abundance on small rodents at all three sites; Dermacentor reticulatus ticks were identified at two sites in small numbers and, finally, numerous juvenile $H$. concinna $(n=427)$ were found at one of our study sites (Nowy Młyn 2). The highest prevalence and abundance of $H$. concinna were recorded on voles, Microtus agrestis and M. oeconomus, from this site in August. Additionally, questing nymphs and adult $H$. concinna were collected locally from vegetation $(\mathrm{n}=20)$. Genotyping and phylogenetic analysis confirmed the species as $H$. concinna. A new focus of $H$. concinna has been described in Western Poland. Our long-term field work monitoring the expansion of the distribution of $D$. reticulatus in Poland, during which all collected ticks are identified, suggests that $H$. concinna is still very rare in the country.
\end{abstract}

Keywords Haemaphysalis concinna $\cdot$ Poland $\cdot$ Rodent $\cdot$ Genotyping

Electronic supplementary material The online version of this article (https://doi.org/10.1007/s1049 3-019-00371-7) contains supplementary material, which is available to authorized users.

Dorota Dwużnik

dorota.dwuznik@biol.uw.edu.pl

1 Department of Parasitology, Institute of Zoology, Faculty of Biology, University of Warsaw, 1 Miecznikowa Street, 02-096 Warsaw, Poland 


\section{Introduction}

Nineteen species of ticks are known to occur in Poland comprising the established tick fauna of the region (Nowak-Chmura and Siuda 2012). The most common species of hard ticks (Ixodidae) are Ixodes ricinus and Dermacentor reticulatus. These two species are subjects of numerous field and laboratory studies, covering the majority of the territory of the country (Asman et al. 2017; Kiewra et al. 2014, 2016; Mierzejewska et al. 2015, 2016; Stańczak et al. 2015, 2018; Wodecka et al. 2014; Wójcik-Fatla et al. 2016; Zając et al. 2017). However, the relict tick Haemaphysalis concinna has never been the subject of such studies because it has been so rare in the Poland. A recent overview of the Polish tick fauna has reported only one previous finding of this tick species in Poland (Nowak-Chmura and Siuda 2012). A single female H. concinna was found in close proximity to the German-Polish border and Baltic Sea shore, in Troszyn, N. West Pomerania in 1953, 65 years ago (Lachmajer et al. 1956).

Interestingly, although the number of field studies on ticks (involving intensive dragging in different habitats and studies on the tick fauna of a wide range of hosts, including wildlife) has increased substantially over the last 20 years, no new foci of $H$. concinna have been reported in Poland. In contrast, the rapid expansion of D. reticulatus has been well documented in Europe (Rubel et al. 2016; Földvári et al. 2016) and also in Central and Western Poland (Mierzejewska et al. 2016, 2017). In a recent review of the distribution of $H$. concinna in Central Europe, Poland was still designated as a 'white spot' region with minimal records, while neighboring countries were recorded as 'red spot' foci reflecting the well-documented presence of the tick: for example in Germany, South Czech Republic, Slovakia, Ukraine and Belarus, South and Eastern Russia (Rubel et al. 2018). Thus, with more vigilant monitoring in the future it will not be surprising to find that more foci of $H$. concinna are recorded in Poland. Moreover, given the well documented climate change and the evidence that it has promoted tick expansion and tick population growth in Europe (Karbowiak 2014; Medlock et al. 2013; Sréter et al. 2005), substantial changes in the distribution of $H$. concinna are also likely to have taken place since its first and only report in the country 65 years ago.

Following our earlier study on the expansion of the distribution of $D$. reticulatus in the period 2012-2014, we also monitored this process subsequently between 2016 and 2018, in order to document further the continued colonization of Western and Central Poland with this important vector of Babesia canis. This study was performed by dragging of suitable open habitats in Spring (March-May) and Autumn (September-November) of each year (Dwużnik unpublished). Additionally, the study was broadened by targeted monitoring of the instars of $D$. reticulatus. For this reason we collected ticks from several rodent communities in Central and Western Poland in the period June-August, when juvenile $D$. reticulatus ticks can be found on rodent hosts (Karbowiak 2009; Paziewska et al. 2010). It was during this work that we encountered also various developmental stages of $H$. concinna in our sampling of both vegetation and on the rodents. In the present study we report a new location for the confirmed presence of $H$. concinna in Western Poland, identified both in the samples of collected questing ticks encountered on vegetation and also feeding ticks removed from rodent hosts. 


\section{Materials and methods}

\section{Field study}

The study was completed in 2018 in Western Poland (Fig. 1). Juvenile ticks were collected from rodents from three sites: Słonin (52.119201N; 16.747274E); Nowy Młyn 1 (52.152127N; 16.119467E) and Nowy Młyn 2 (52.148505N; 16.114098E). Trapping was performed at all sites in June-July (the season for occurrence of D. reticulatus larvae) and in August in Nowy Młyn 2 and Słonin (D. reticulatus nymph season). The distance between Słonin and Nowy Młyn is about $50 \mathrm{~km}$, and that between Nowy Młyn 1 and Nowy Młyn 2 is about $1 \mathrm{~km}$. Additionally, Nowy Młyn 1 and Nowy Młyn 2 sites were separated by a road (Fig. 1).

The habitats at the three locations were similar, comprising submerged meadows and fallow lands in close proximity to water bodies (water ditch in Słonin, Dojca River in Nowy Młyn 1, Dojca River and large breeding pond in Nowy Młyn 2). Each of the trapping sites was located in the vicinity of forests. All locations were selected on the basis of habitat qualities typical of the preferred habitats for Microtus spp. voles which are the main hosts of $D$. reticulatus instars, this tick species being the main focus of our field work (Paziewska et al. 2010).

Small rodents were live-trapped and live-processed at the site of trapping, as described in our previous papers (Bajer et al. 2014; Grzybek et al. 2015; Tołkacz et al. 2017), including the removal of ticks and other ectoparasites from anesthetized animals. Rodents were then released near to their trapping points.

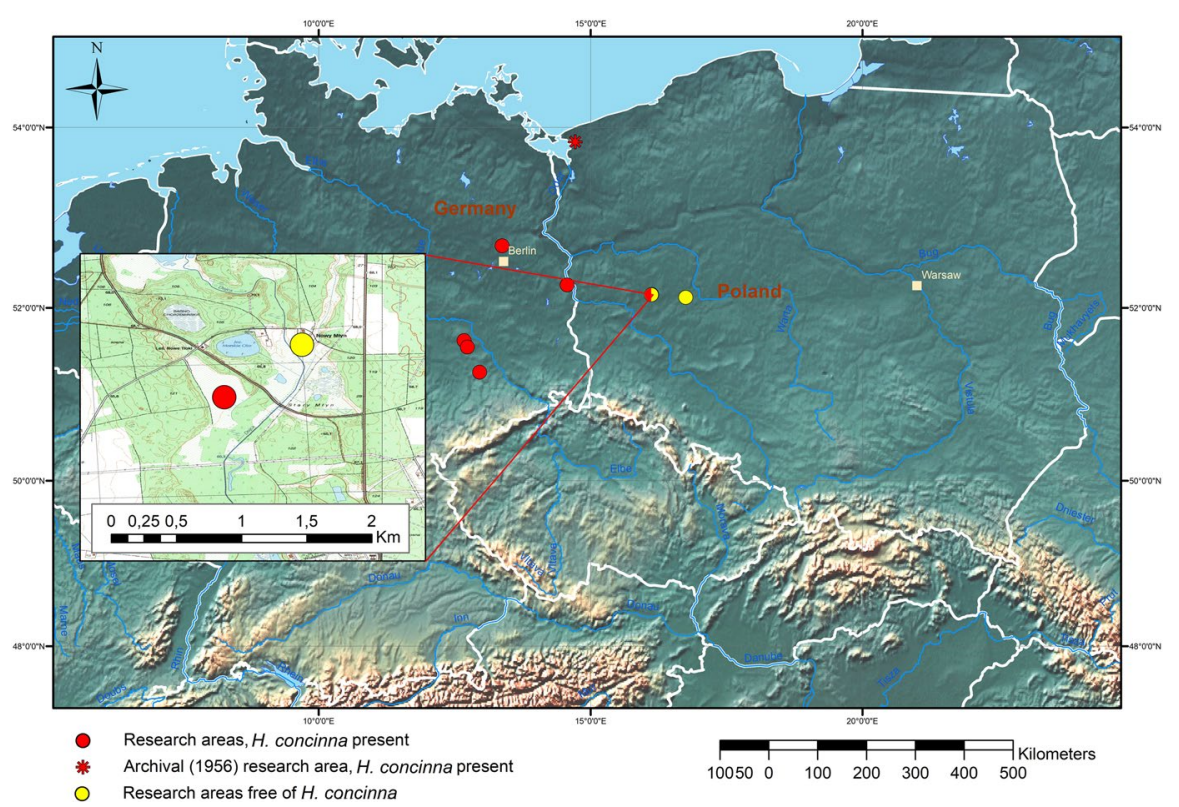

Fig. 1 Map of Haemaphysalis concinna occurrence in Poland 
Additionally, during the inspection of traps in Nowy Młyn 2 site in August 2018 questing adult ticks and nymphs were collected along a $300 \mathrm{~m}$ transect from two researchers and their accompanying dog.

\section{Tick identification}

Ticks were fixed in $70 \% \mathrm{EtOH}$, transported to the laboratory of the Department of Parasitology, Faculty of Biology, University of Warsaw and identified to species and stage levels using a stereoscopic microscope Zeiss Stemi 508 equipped with a camera. All ticks were assigned to species and stages according to the key of Estrada-Peña et al. (2004). Photographical documentation was performed. Ticks were counted and two infestation parameters were calculated: prevalence (\% infested rodents) and abundance (mean number of tick/ individual). For questing ticks we calculated the mean density $/ 100 \mathrm{~m}^{2}$ of territory.

\section{Genotyping of ticks}

Genomic DNA was extracted from four ticks (4 nymphs) collected from rodents at the Nowy Młyn 2 site and identified as $H$. concinna, using the A\&A Biotechnology DNA extraction kit (Gdańsk, Poland). Variable mitochondrial (mt) 16S rRNA gene fragment (440 bp) was amplified following Kulakova et al. (2014).

PCR products were sequenced by a private company (Genomed, Warsaw, Poland). DNA sequence alignments and analyses were conducted using MEGA 7. Consensus sequences were compared with sequences deposited in the GenBank database (http://www.ncbi.nlm. nih.gov/genbank/).

For the phylogenetic analysis, the Akaike information criterion was used in jModel Test to identify the most appropriate model of nucleotide substitution. A representative tree for mt16S rDNA was constructed using MEGA 7 by the Maximum Likelihood method and the General Time Reversible model with Gamma distribution (Kumar et al. 2016).

\section{Ethics approval}

All of the procedures were conducted with the approval of the First Warsaw Local Ethics Committee for Animal Experimentation in Poland (ethical license number: 706/2015) according to the principles governing experimental conditions and care of laboratory animals required by the European Union and the Polish Law on Animal Protection.

\section{Results}

\section{Ticks from rodents}

A total of 106 rodents were examined for ectoparasites, including 22 Apodemus agrarius, 14 A. flavicollis, six A. sylvaticus, 51 Microtus oeconomus, six M. agrestis, one M. arvalis, three Mus musculus and three juvenile Microtus voles (Microtus spp.), which could not be identified to species level due to their very small body size (juvenile $M$. agrestis and $M$. oeconomus are morphologically almost identical). 
Altogether 1482 feeding ticks were collected from these rodents at our three study sites, including 13 D. reticulatus (1 larva and 12 nymphs), 1042 I. ricinus (972 larvae and 70 nymphs) and $427 H$. concinna (405 larvae and 22 nymphs). The $H$. concinna ticks were collected only at Nowy Młyn 2 site (Figs. 1 and 2). A representative larva and nymph, identified as H. concinna, are illustrated in Fig. 3.

Ixodes ricinus was the most common species of tick on rodents from the three sites (Table 1). Total prevalence of this species ranged only between 82 and 95\%, mainly due to high infestation with $I$. ricinus larvae. Mean abundance was also similar between sites (NS). Juvenile $D$. reticulatus ticks were found only in two rodent communities in low numbers, resulting in an overall low prevalence and abundance (Table 1). Ticks identified as $H$. concinna were found at the Nowy Młyn 2 site and at this site constituted the second most numerous tick species: $427 \mathrm{H}$. concinna were collected from 39 rodents in comparison to

A Słonin

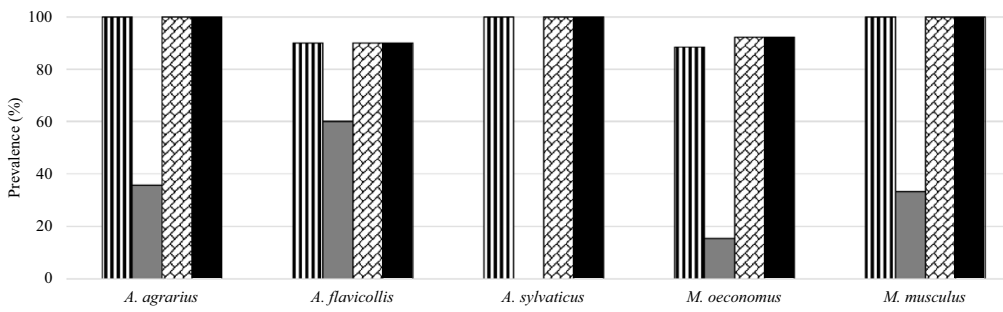

B Nowy Młyn 1

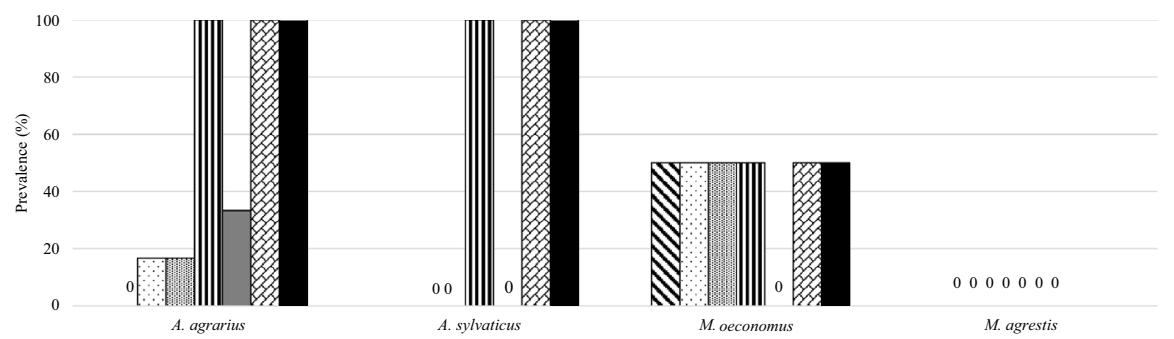

C Nowy Młyn 2

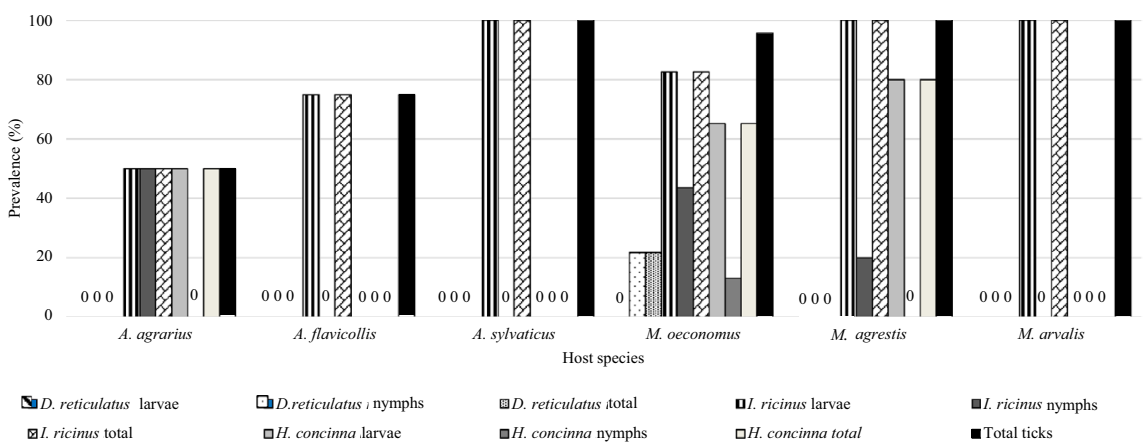

Fig. 2 Prevalence of three tick species (Dermacentor reticulatus, Ixodes ricinus and Haemaphysalis concinna) by site and host species (Apodemus agrarius, A. flavicollis, A. sylvaticus, Microtus oeconomus, M. agrestis and Mus musculus) 

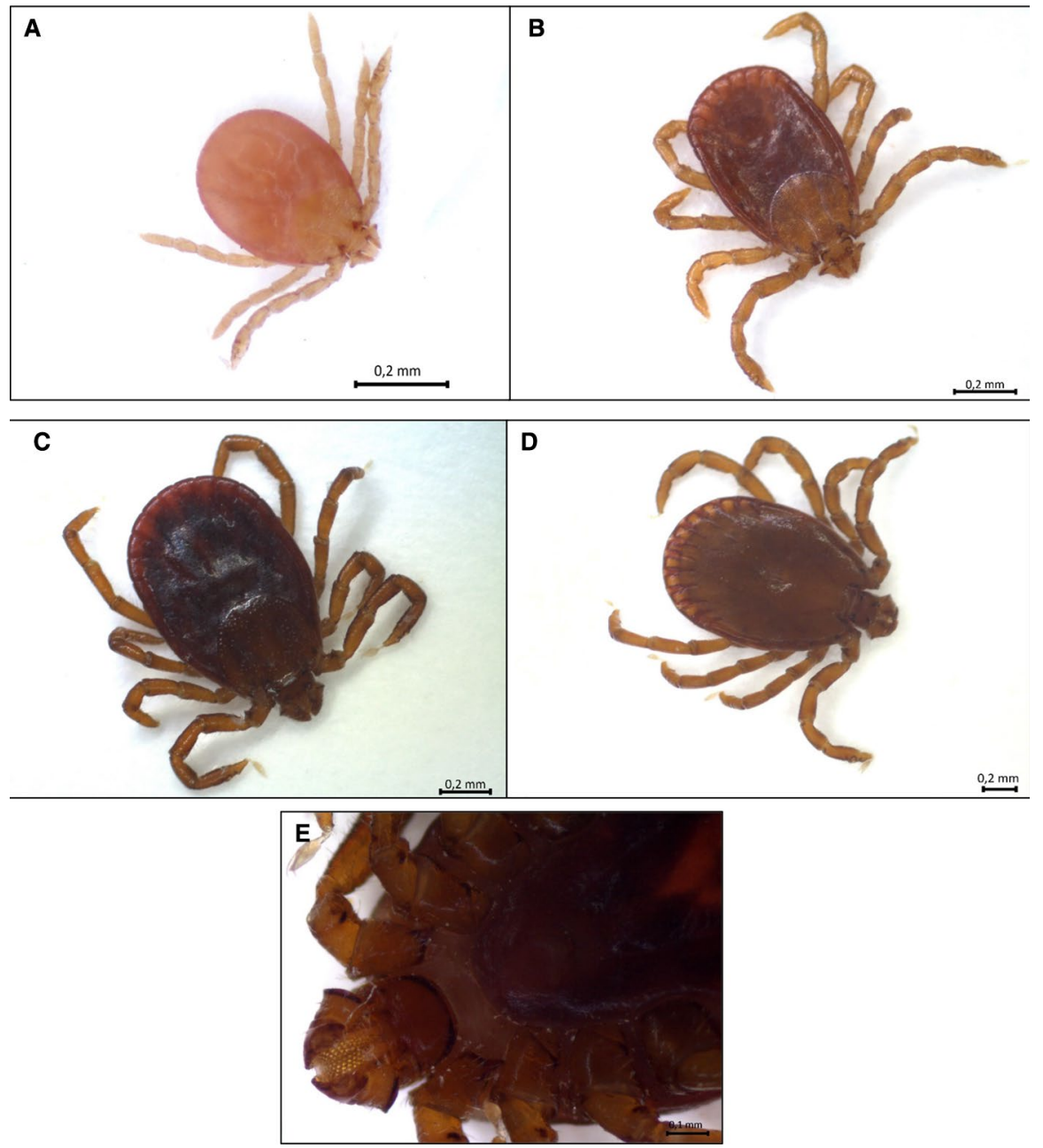

Fig. 3 Pictures of Haemaphysalis concinna larva (A), nymph (B), female (C), male (D) and hypostom (E)

443 I. ricinus and 10 D. reticulatus. Prevalence of infestation with $H$. concinna was above $50 \%$ at this site, and mean abundance exceeded 4 ticks/rodent, mainly due to the high number of $H$. concinna larvae.

Comparisons of the prevalence and abundance of the three tick species on the different species of rodents at individual sites are presented in Supplementary file 1 (Supplementary Tables 1-3). Prevalence of tick species, by host species and site, is presented in Fig. 2. Juvenile $I$. ricinus ticks were found on all inspected rodent species. Juvenile $D$. reticulatus ticks were found on A. agrarius and $M$. oeconomus, and $H$. concinna ticks were also found on A. agrarius and two vole species: M. oeconomus and M. agrestis (and on three unidentified juvenile Microtus) (Fig. 2). Both high prevalence (65-80\%) and high mean abundance 


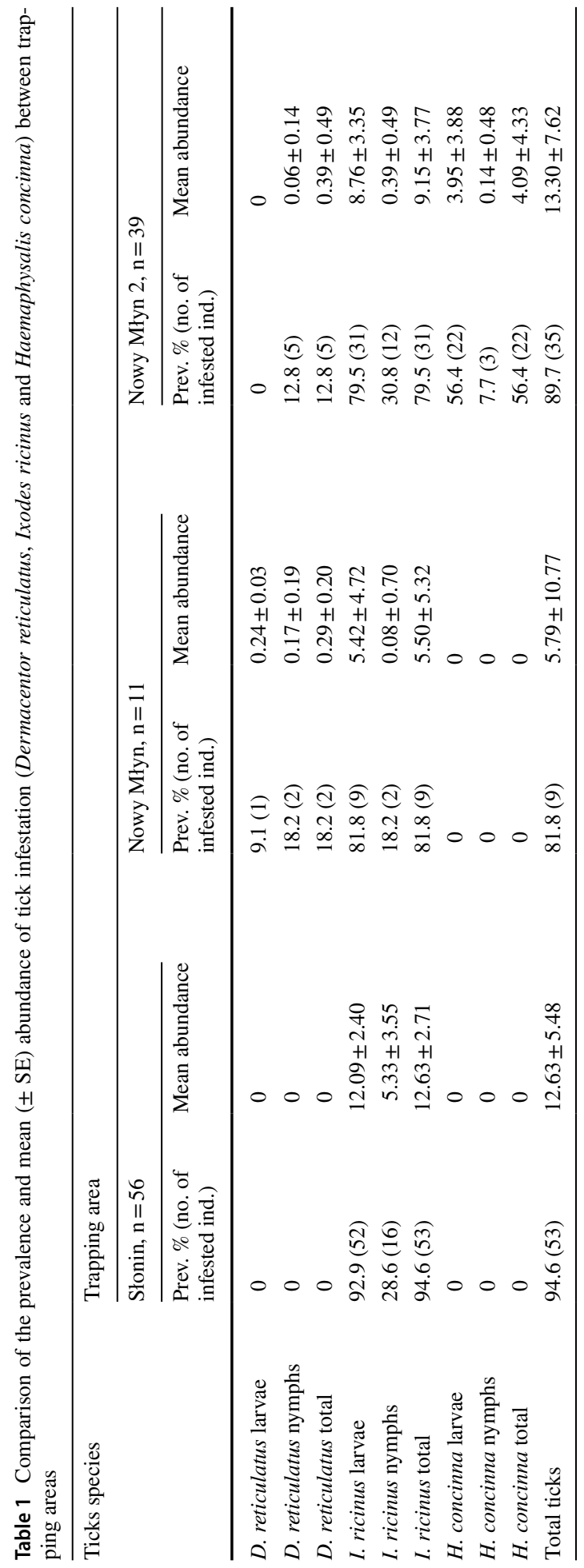




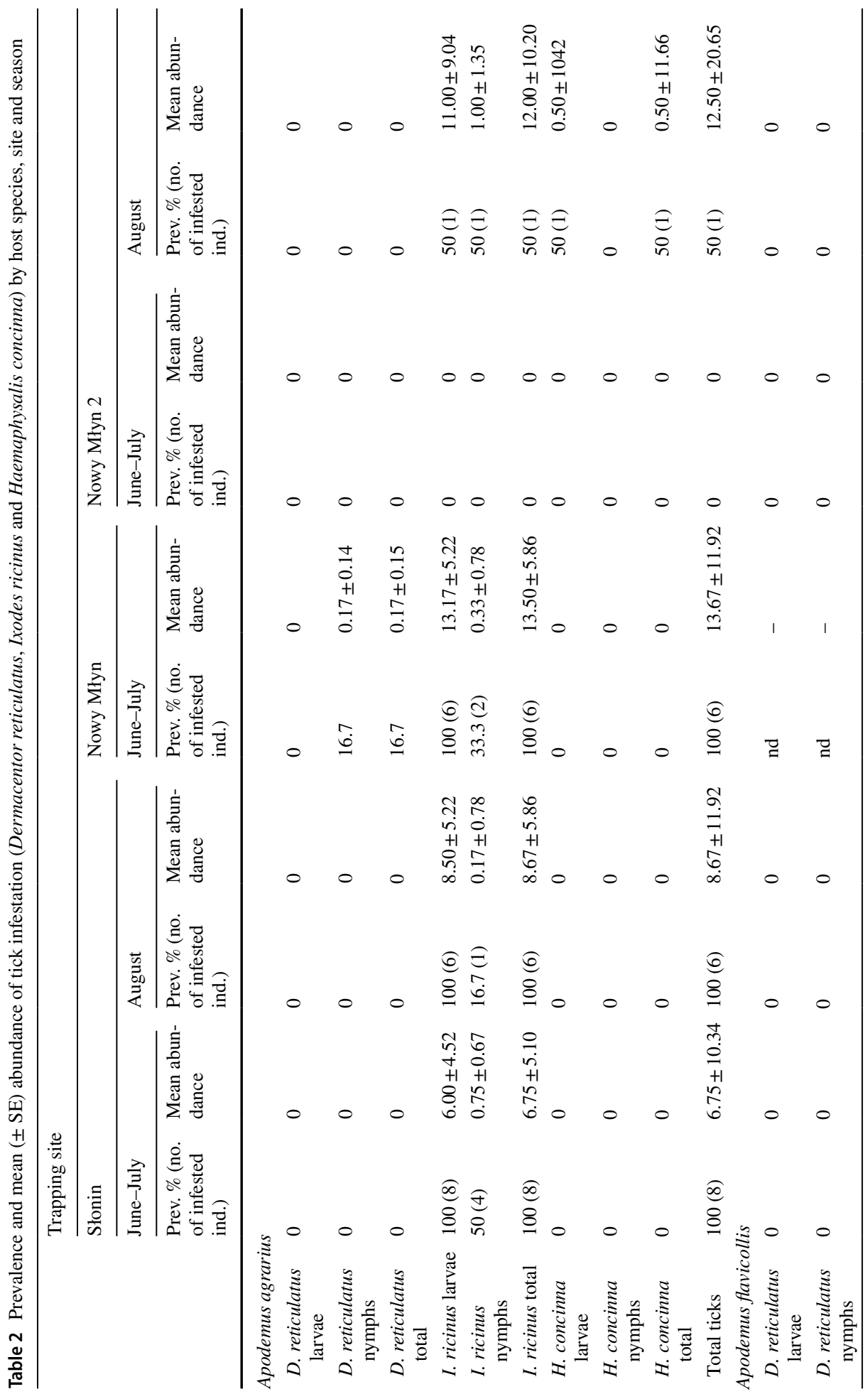




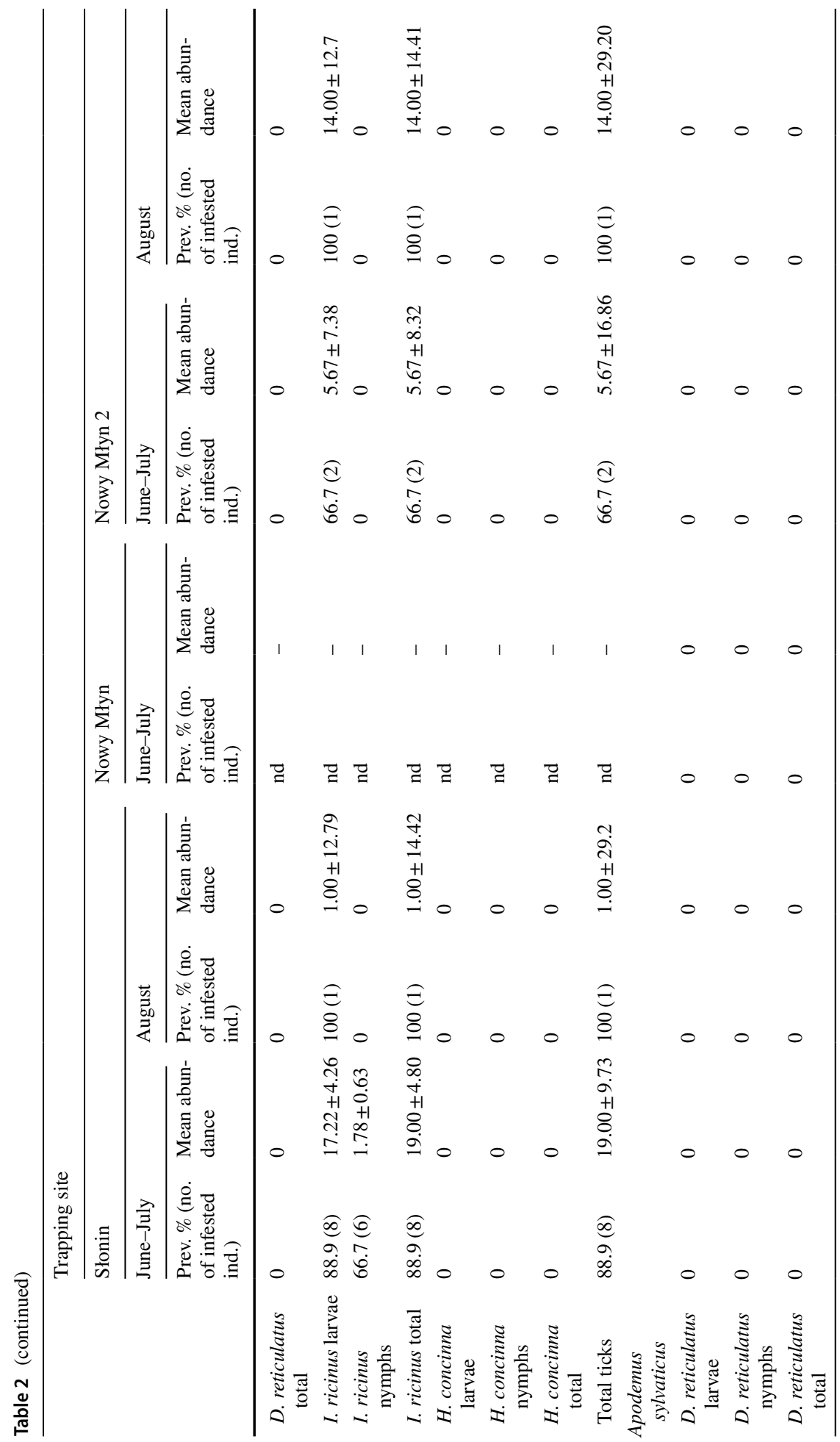




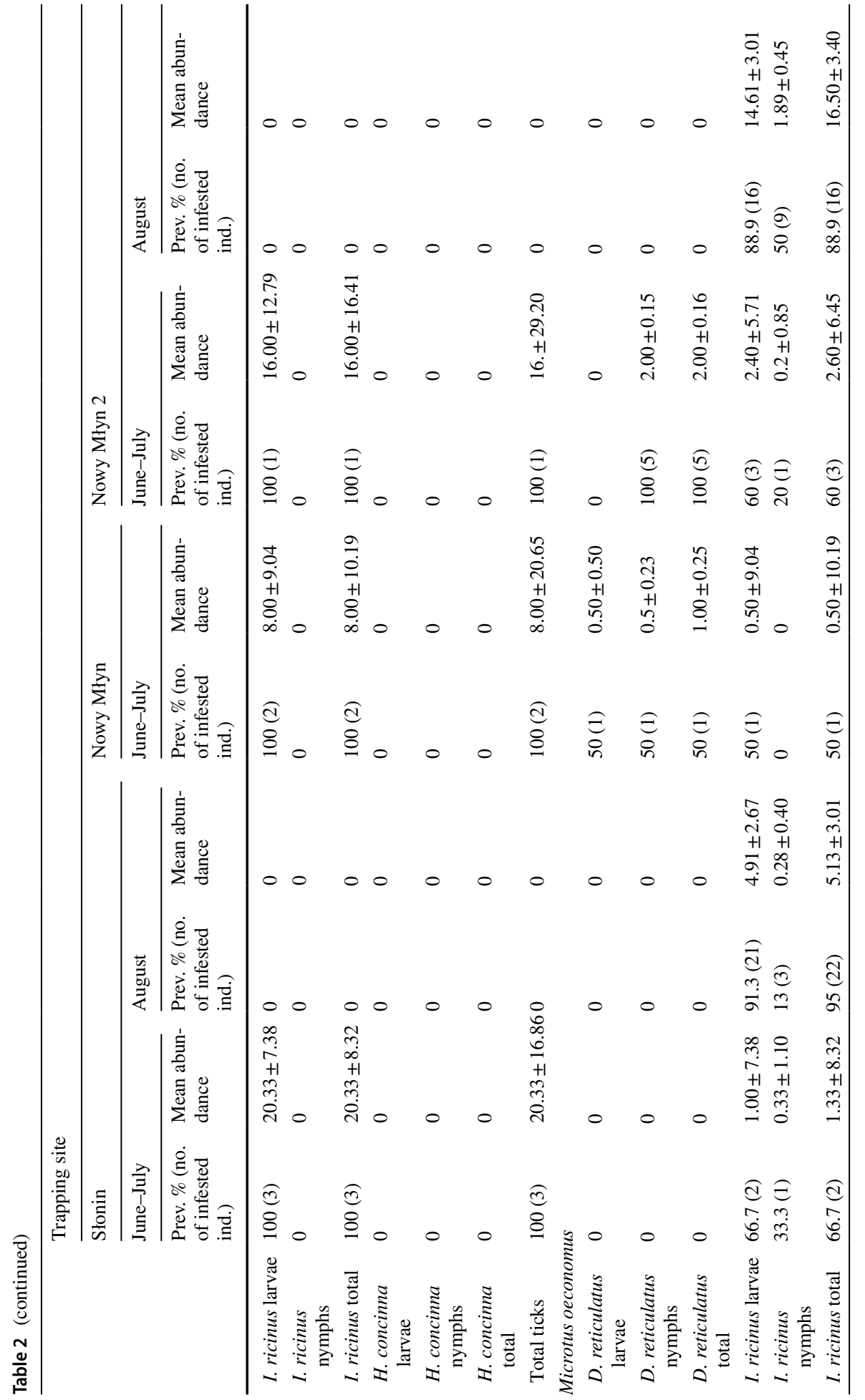




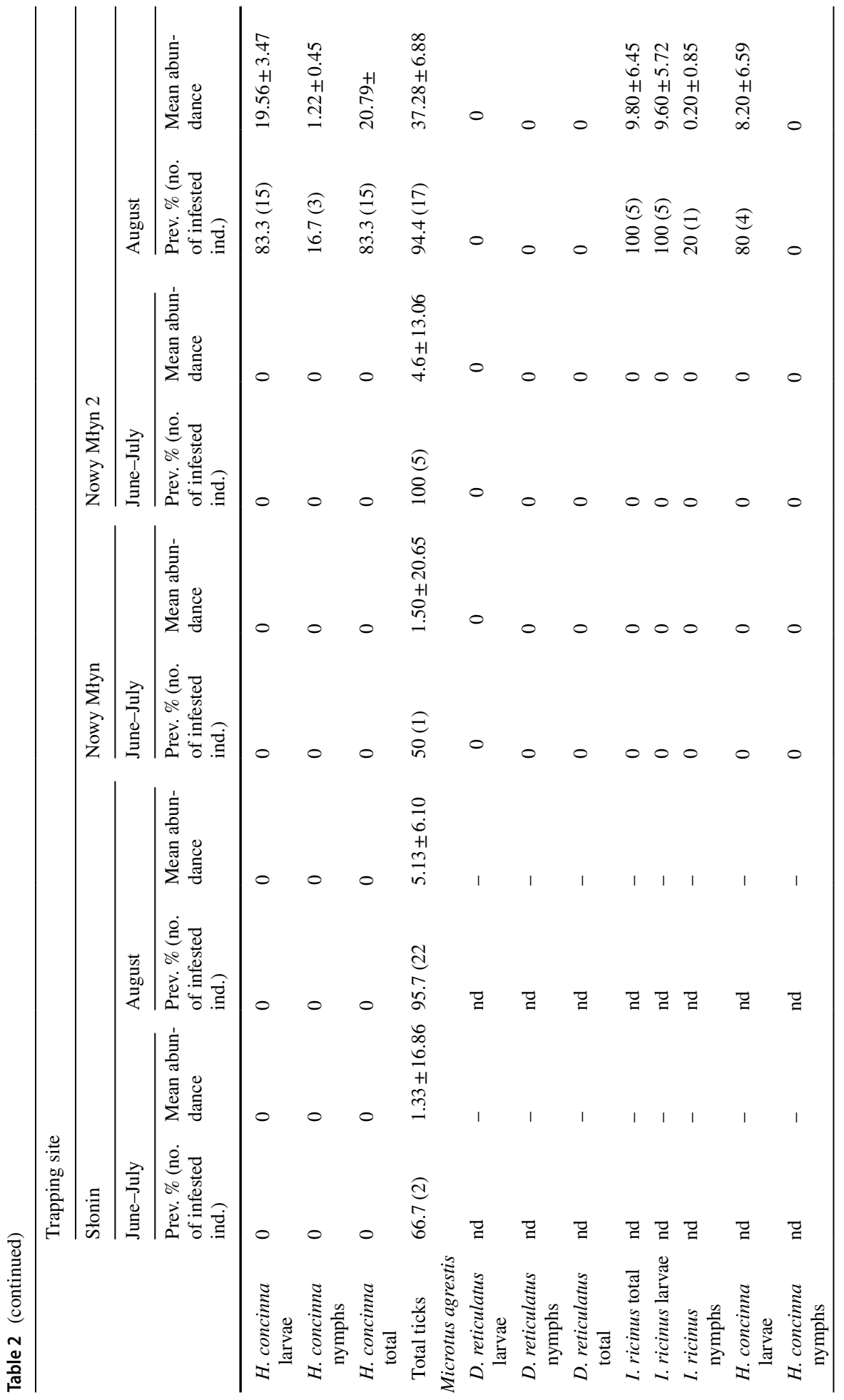




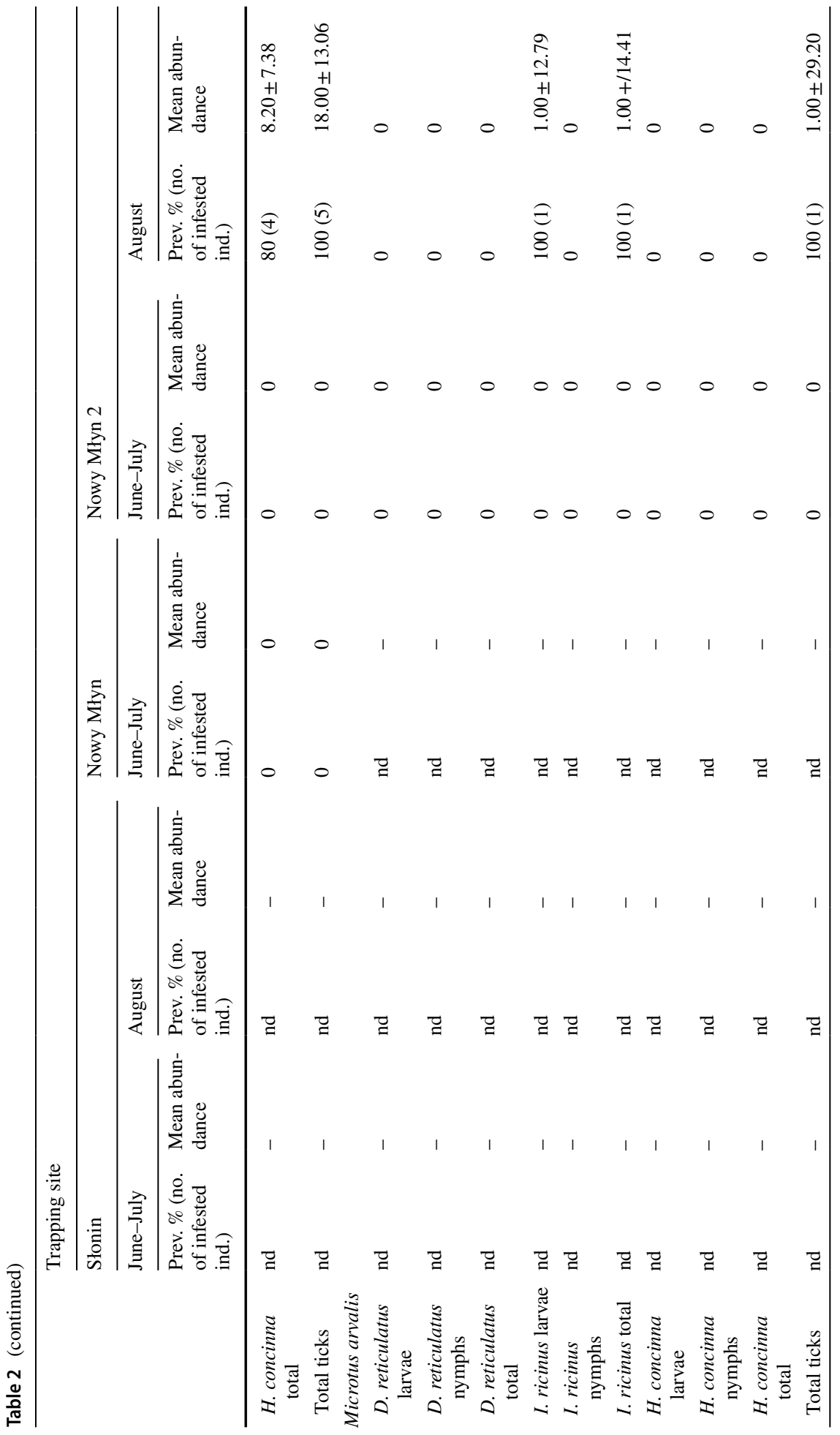




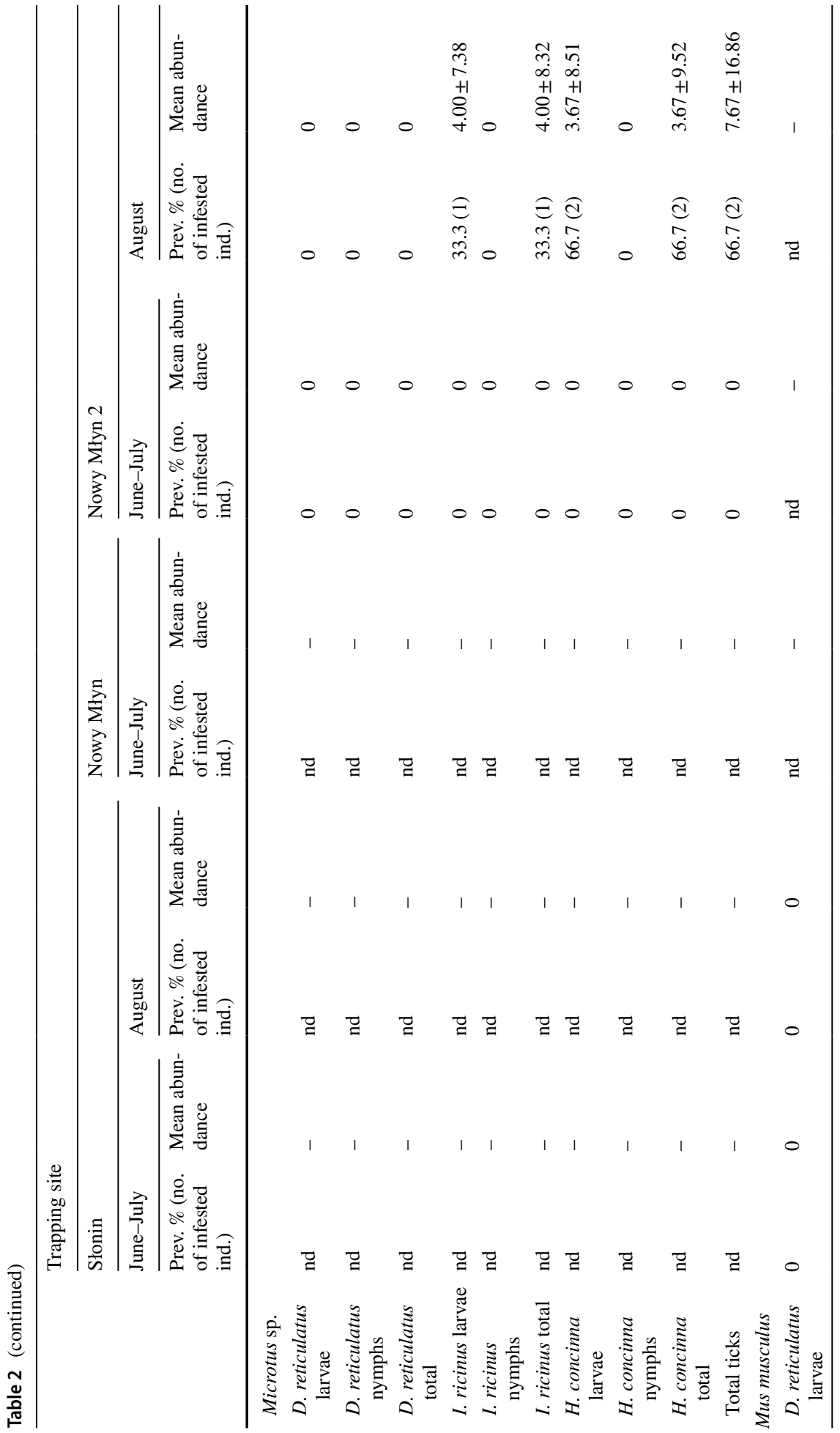




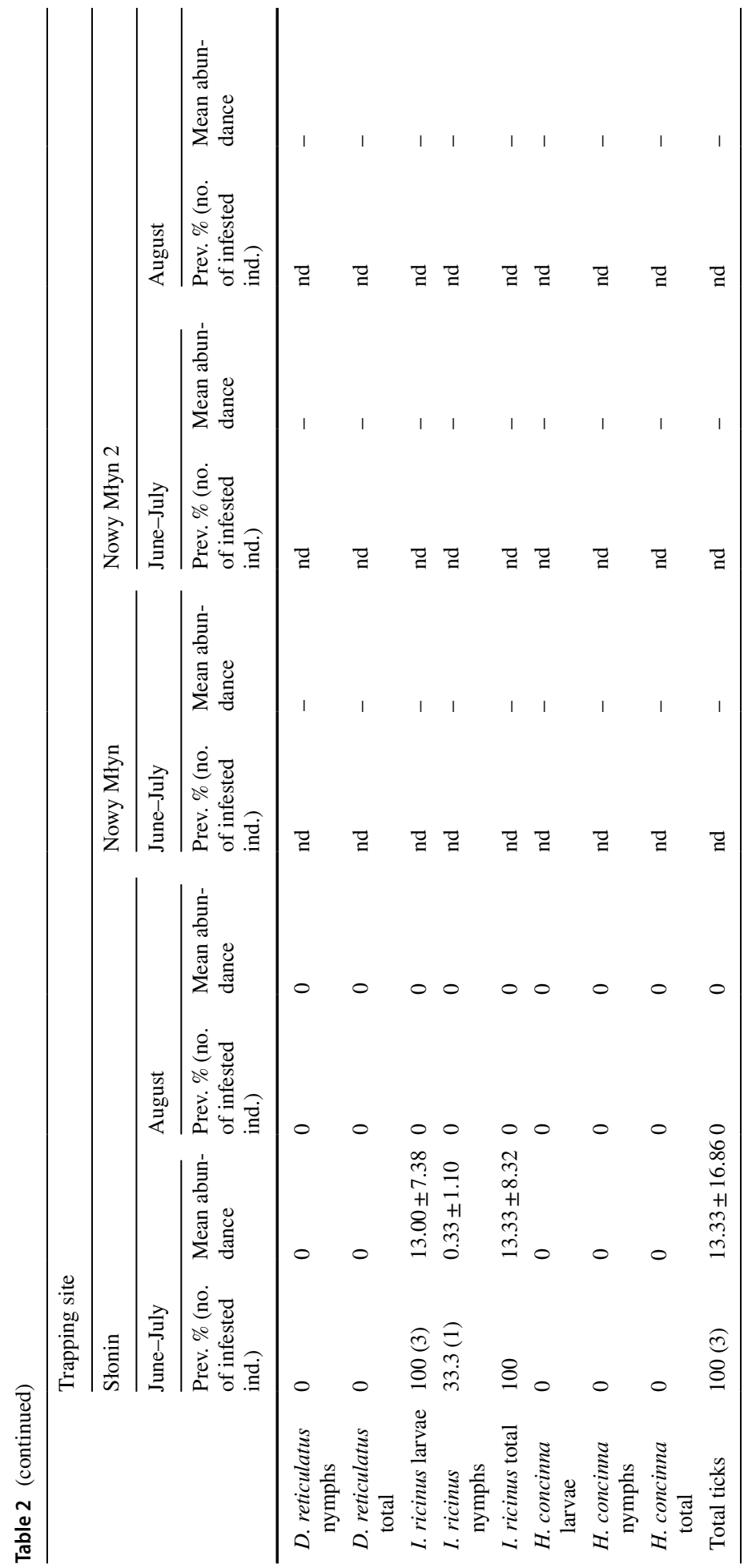


(4-16 ticks/host) of $H$. concinna infestation were noted on Microtus voles from Nowy Młyn 2 (Supplementary File 1: Supplementary Table 3). Interestingly, no H. concinna ticks were found on rodents in early summer (June-July) but both larvae and nymphs appeared on rodents in August (Table 2). At that time both prevalence and abundance of H. concinna were highest on $M$. agrestis and M. oeconomus, exceeding $83 \%$ and 21 ticks/host for the latter species (Table 2).

\section{Questing ticks}

In August 2018, 20 questing ticks were collected in Nowy Młyn 2 from two researchers and their accompanying dog, to whom they had attached while checking traps over a $300 \mathrm{~m}$ long transect. All ticks were morphologically identified as $H$. concinna, including $3 H$. concinna females, one male and 16 nymphs. Representative female and male of $H$. concinna are presented in Fig. 3. The mean density of $H$. concinna in this location was estimated at 3.33 ticks $/ 100 \mathrm{~m}^{2}$.

\section{Genotyping and phylogenetic analysis}

Four mt 16S rDNA sequences were obtained from 4 nymphs morphologically identified as H. concinna. Three consensus sequences showed the highest similarity $(404 / 405=99.75 \%)$ to a H. concinna sequence from Japan (GenBank: AB819173) and 99.51\% (404/406) to a H. concinna sequence from Hungary (GenBank: KU170525). This first identified genotype has been deposited in the GenBank database under accession number MK418863. Fourth sequence (deposited with accession number MK463620) differed by five positions (one insertion, four A-T substitutions) from the three former sequences, representing second genotype, and showed the highest similarity-98.76\% (399/404) to a sequence from Japan (Gen Bank: AB819171).

A phylogenetic tree incorporating sequences obtained in this study is presented in Fig. 4. All sequences grouped with H. concinna from Europe and Japan. 


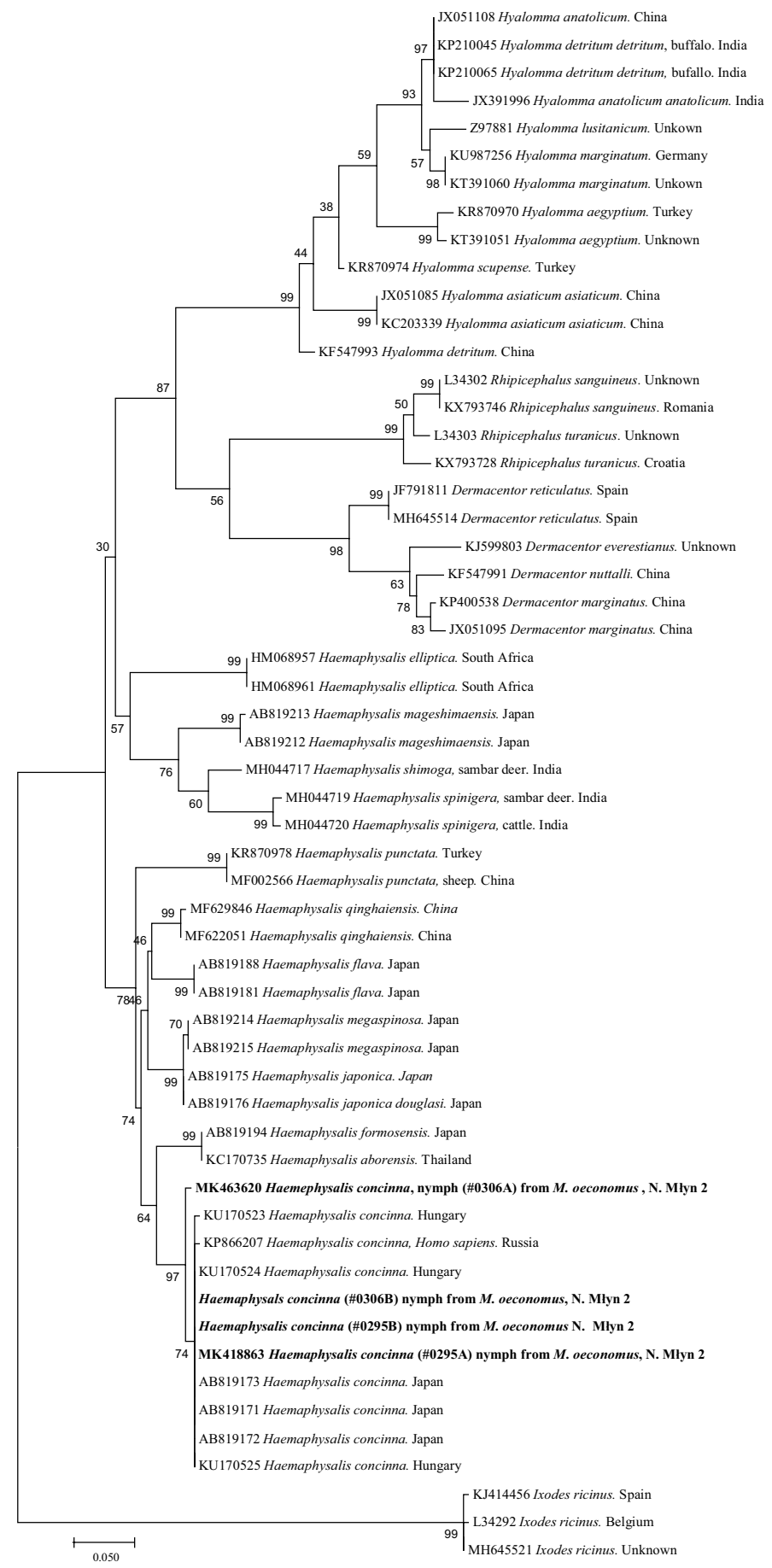


4 Fig. 4 Molecular phylogenetic analysis of Ixodidae by Maximum Likelihood method. The evolutionary history was inferred by using the Maximum Likelihood method based on the General Time Reversible model (Nei and Kumar 2000). The tree with the highest log likelihood (- 2079.4170) is shown. The percentage of trees in which the associated taxa clustered together is shown next to the branches. Initial tree(s) for the heuristic search were obtained automatically by applying Neighbor-Join and BioNJ algorithms to a matrix of pairwise distances estimated using the Maximum Composite Likelihood (MCL) approach, and then selecting the topology with superior log likelihood value. A discrete Gamma distribution was used to model evolutionary rate differences among sites $(5$ categories $(+\mathrm{G}$, parameter $=0.3748)$ ). The rate variation model allowed for some sites to be evolutionarily invariable ([+I], 20.7364\% sites). The tree is drawn to scale, with branch lengths measured in the number of substitutions per site. The analysis involved 56 nucleotide sequences. All positions containing gaps and missing data were eliminated. There were a total of 286 positions in the final dataset. Evolutionary analyses were conducted in MEGA7 (Kumar et al. 2016)

\section{Discussion}

A new well-established focus of $H$. concinna has been identified in Western Poland both through the collection of questing ticks from vegetation and feeding ticks from several rodent hosts. The identity of this tick species was confirmed by morphological criteria and by amplification and sequencing of mt $16 \mathrm{~S}$ rDNA.

In comparison to the dynamic changes in distribution of many arthropod vectors, including ticks, the finding of one new focus of $H$. concinna 65 years after the first identification of this species in Western Poland may suggest a low overall ability of this tick to expand locally and to establish in a new territory. Looking at the distances involved, the new site is located about $100 \mathrm{~km}$ from the German-Polish border, where at least one known focus is present (Hagedorn 2013; Rubel et al. 2018). It is also located $200 \mathrm{~km}$ to the south of a previously described focus in Troszyn in NW Poland. There is no evidence that these sites could have served as the source of this newly recognized $H$. concinna population. Interestingly, the distribution of this tick species is very focal and rather restricted: no ticks of this species were found on rodents trapped $1 \mathrm{~km}$ south from the new focus at Nowy Młyn 1, nor $50 \mathrm{~km}$ east in Słonin. Accordingly, no questing $H$. concinna ticks were found during our previous monitoring surveys of $D$. reticulatus expansion in Central and Western Poland in 2012-2014 (Mierzejewska et al. 2016), nor during the present monitoring in 2016-2018 (Dwużnik, unpublished), when in this period a high number of sites $(>100)$ were regularly visited and sampled. Interestingly, in support of the rare occurrence of $H$. concinna in Poland, no ticks of this species were found on dogs from Central (Zygner and Wedrychowicz 2006; Mierzejewska et al. 2015), South (Kilar 2011) or Western Poland (Król et al. 2016a, b). Also in our long-term studies on rodent parasites in the Mazury Lake District (Bajer 2008; Bajer et al. 2001, 2002, 2005, 2014; Behnke et al. 2001, 2008a, b; Grzybek et al. 2015; Tołkacz et al. 2017), where the number of studied rodents is currently in excess of 4000, yet to-date no H. concinna have been found (Pawełczyk and Siński 2004; WelcFalęciak et al. 2008; Paziewska et al. 2010).

Such a limited distribution of $H$. concinna in Poland is surprising, given that this tick species is known to be capable of inhabiting different habitats and climatic zones (Rubel et al. 2018) and is widespread in Germany (Hagedorn 2013) and Austria (where it is the dominant tick species on dogs in summer months; Duscher et al. 2013).

As $H$. concinna is a proven or suggested vector of a wide range of pathogens, including tick-borne encephalitis, Anaplasma phagocytophilum and Rickettsia spp. (reviewed in Rubel et al. 2018), the finding of this new focus in Poland is of considerable local concern. This tick species may feed on both human and domestic animal hosts, as found also in our study although ticks had been removed before they started feeding. Our results are therefore of public health relevance, contributing to the understanding of the risk of tick-borne 
diseases in regions where this tick species is endemic, and we emphasize the need for increased awareness of its presence and continued monitoring for potential expansion of its range.

\section{Conclusions}

In the present study we report a new focus of $H$. concinna in Western Poland, identified both by the collection of questing ticks from vegetation and feeding ticks from several rodent hosts. Moreover, we confirm that this is still a rare and uncommon species in other regions of Poland.

Acknowledgements The study was supported by National Science Centre (NCN) Sonata Bis Grant No. 2014/14/E/NZ7/00153.

Open Access This article is distributed under the terms of the Creative Commons Attribution 4.0 International License (http://creativecommons.org/licenses/by/4.0/), which permits unrestricted use, distribution, and reproduction in any medium, provided you give appropriate credit to the original author(s) and the source, provide a link to the Creative Commons license, and indicate if changes were made.

\section{References}

Asman M, Nowak-Chmura M, Solarz K, Szilman E, Semla M, Zyśk B (2017) Anaplasma phagocytophilum, Babesia microti, Borrelia burgdorferi sensu lato, and Toxoplasma gondii in Ixodes ricinus (Acari, Ixodidae) ticks collected from Słowiński National Park (Northern Poland). J Vector Ecol 42:200-202. https://doi.org/10.1111/jvec.12258

Bajer A (2008) Between-year variation and spatial dynamics of Cryptosporidium spp. and Giardia spp. infections in naturally infected rodent populations. Parasitology 135:1629-1649

Bajer A, Pawełczyk A, Behnke JM, Gilbert FS, Siński E (2001) Factors affecting the component community structure of haemoparasites in bank voles (Clethrionomys glareolus) from the Mazury Lake District region of Poland. Parasitology 122:43-54

Bajer A, Bednarska M, Pawełczyk A, Behnke JM, Gilbert FS, Siński E (2002) Prevalence and abundance of Cryptosporidium parvum and Giardia spp. in wild rural rodents from the Mazury Lake District region of Poland. Parasitology 125:21-34

Bajer A, Behnke JM, Pawełczyk A, Kuliś K, Sereda MJ, Siński E (2005) Medium-term temporal stability of the helminth component community structure in bank voles (Clethrionomys glareolus) from the Mazury Lake District region of Poland. Parasitology 130:213-228

Bajer A, Welc-Falęciak R, Bednarska M, Alsarraf M, Behnke-Borowczyk J, Siński E, Behnke JM (2014) Long-term spatiotemporal stability and dynamic changes in the haemoparasite community of bank voles (Myodes glareolus) in NE Poland. Microb Ecol 68:196-211

Behnke JM, Barnard CJ, Bajer A, Bray D, Dinmore J, Frake K, Osmond J, Race T, Siński E (2001) Variation in the helminth community structure in bank voles (Clethrionomys glareolus) from three comparable localities in the Mazury Lake District region of Poland. Parasitology 123:401-414

Behnke JM, Bajer A, Harris PD, Newington L, Pidgeon E, Rowlands G, Sheriff C, Kuliś K, Siński E, Gilbert FS, Barnard CJ (2008a) Temporal and between-site variation in helminth communities of bank voles (Myodes glareolus) from NE Poland. 1. Regional fauna and component community levels. Parasitology 135:985-997

Behnke JM, Bajer A, Harris PD, Newington L, Pidgeon E, Rowlands G, Sheriff C, Kuliś-Malkowska K, Siński E, Gilbert FS, Barnard CJ (2008b) Temporal and between-site variation in helminth communities of bank voles (Myodes glareolus) from NE Poland. 2. The infracommunity level. Parasitology 135:999-1018 
Duscher GG, Feiler A, Leschnik M, Joachim A (2013) Seasonal and spatial distribution of ixodid tick species feeding on naturally infested dogs from Eastern Austria and the influence of acaricides/ repellents on these parameters. Parasit Vectors 6:76. https://doi.org/10.1186/1756-3305-6-76

Estrada-Peña A, Bouattour A, Camicas J-L, Walker AR (2004) Ticks of domestic animals in the Mediterranean region: a guide to identification of species. University of Zaragoza, Saragossa

Földvári G, Široký P, Szekeres S, Majoros G, Sprong H (2016) Dermacentor reticulatus: a vector on the rise. Parasit Vectors 9:314

Grzybek M, Bajer A, Bednarska M, Alsarraf M, Behnke-Borowczyk J, Harris P, Price SJ, Brown GS, Osborne S-J, Siński E, Behnke JM (2015) Long-term spatiotemporal stability and dynamic changes in helminth infracommunities of bank voles (Myodes glareolus) in NE Poland. Parasitology 142:1722-1743

Hagedorn P (2013) Untersuchung von Zeckenals Marker für die GefährdungDurch von Ihnen Übertragene Krankheiten. Dissertation

Karbowiak G (2009) Kleszcz łąkowy Dermacentor reticulatus- występowanie, biologa i rola jako wektora chorób odkleszczowych. Habilitation thesis. Ed. Instytut Parazytologii im. Witolda Stefańskiego PAN, Warsaw (in Polish)

Karbowiak G (2014) The occurrence of the Dermacentor reticulatus tick-its expansion to new areas and possible causes. Ann Parasitol 60:37-47

Kiewra D, Stańczak J, Richter M (2014) Ixodesricinus ticks (Acari, Ixodidae) as a vector of Borrelia burgdorferi sensu lato and Borrelia miyamotoi in Lower Silesia, Poland-preliminary study. Ticks Tick Borne Dis 5:892-897. https://doi.org/10.1016/j.ttbdis.2014.07.004

Kiewra D, Czułowska A, Lonc E (2016) Winter activity of Dermacentor reticulatus (Fabricius, 1794) in the newly emerging population of Lower Silesia, south-west Poland. Ticks Tick Borne Dis 7:11241127. https://doi.org/10.1016/j.ttbdis.2016.08.012

Kilar P (2011) Ticks attacking domestic dogs in the area of the Rymanów district, Subcarpathian province, Poland. Wiad Parazytol 57:189-191

Król N, Kiewra D, Lonc E, Janaczyk B, Chodorowska-Skubiszewska A, Dzięcioł M, Gola M, Gruszka R, Jackowska-Szlachcic E, Jagiełło M, Kawski S, Łukaszewski Z, Mizgalski P, Narajowska T, Niedzielska J, Noczyński M, Rudkowska M, Rzepka D, Samulska K, Senze M, Sieczko P, Silny A, Staniewska A, Stańczyk J, Stańczyk W, Stasiak M, Włodarczyk M, Zimniak S (2016a) Dermacentor reticulatus (Fabricius, 1794) and Babesia canis (Piana et Galli-Valerio, 1895) as the parasites of companion animals (dogs and cats) in the Wrocław area, south-western Poland. Ann Parasitol 62:125-130. https://doi.org/10.17420/ap6202.44

Król N, Obiegala A, Pfeffer M, Lonc E, Kiewra D (2016b) Detection of selected pathogens in ticks collected from cats and dogs in the Wrocław Agglomeration, South-West Poland. Parasit Vectors 9:351. https://doi.org/10.1186/s13071-016-1632-0

Kulakova NV, Khasnatinov MA, Sidorova EA, Adel'shin RV, Belikov SI (2014) Molecular identification and phylogeny of Dermacentor nuttalli (Acari: Ixodidae). Parasitol Res 113:1787-1793

Kumar S, Stecher G, Tamura K (2016) MEGA 7: molecular evolutionary genetics analysis version 7.0 for bigger datasets. Mol Biol Evol 33:1870-1874

Lachmajer J, Skierska B, Wegner Z (1956) Kleszcze rodzaju Haemaphysalis Koch (Ixodidae) znalezione na terenie Polski. Biul Państw Inst Med Morsk Trop J W Gdańsku 7:189-195

Medlock JM, Hansford KM, Bormane A, Derdakova M, Estrada-Peña A, George JC, Golovljova I, Jaenson TG, Jensen JK, Jensen PM, Kazimirova M, Oteo JA, Papa A, Pfister K, Plantard O, Randolph SE, Rizzoli A, Santos-Silva MM, Sprong H, Vial L, Hendrickx G, Zeller H, Van Bortel W (2013) Driving forces for changes in geographical distribution of Ixodes ricinus ticks in Europe. Parasit Vectors 6:1

Mierzejewska EJ, Welc-Falęciak R, Karbowiak G, Kowalec M, Behnke JM, Bajer A (2015) Dominance of Dermacentor reticulatus over Ixodes ricinus (Ixodidae) on livestock, companion animals and wild ruminants in Poland. Exp Appl Acarol 66:83-101

Mierzejewska EJ, Estrada- Peña A, Alsarraf A, Kowalec M, Bajer A (2016) Mapping of tick Dermacentor reticulatus expansion in Poland in 2012-2014. Ticks Tick Borne Dis 7:94-106

Mierzejewska EJ, Estrada-Peña A, Bajer A (2017) Spread of Dermacentor reticulatus is associated with the loss of forest area. Exp Appl Acarol 72:399-413. https://doi.org/10.1007/s10493-017-0160-8

Nei M, Kumar S (2000) Molecular evolution and phylogenetics. Oxford University Press, New York

Nowak-Chmura M, Siuda K (2012) Ticks of Poland. Review of contemporary issues and latest research. Ann Parasitol 58:125-155

Pawełczyk A, Siński E (2004) Prevalence of Ixodes ricinus infection with Borrelia burgdorferi s.l.: seasonal and annual variations. Wiad Parazytol 50:253-258 (in Polish) 
Paziewska A, Zwolińska L, Harris PD, Bajer A, Siński E (2010) Utilisation of rodent species by larvae and nymphs of hard ticks (Ixodidae) in two habitats in NE Poland. Exp Appl Acarol 50:79-91

Rubel F, Brugger K, Pfeffer M, Chitimia-Dobler L, Didyk YM, Leverenz S, Dautel H, Kahl O (2016) Geographical distribution of Dermacentor marginatus and Dermacentor reticulatus in Europe. Ticks Tick Borne Dis 7:224-233

Rubel F, Brugger K, Walter M, Vogelgesang JR, Didyk YM, Fu S, Kahl O (2018) Geographical distribution, climate adaptation and vector competence of the Eurasian hard tick Haemaphysalis concinna. Ticks Tick Borne Dis 9:1080-1089. https://doi.org/10.1016/j.ttbdis.2018.04.002

Sréter T, Széll Z, Varga I (2005) Spatial distribution of Dermacentor reticulatus and Ixodes ricinus in Hungary: evidence for change? Vet Parasitol 128:347-351

Stańczak J, Cieniuch S, Lass A, Biernat B, Racewicz M (2015) Detection and quantification of Anaplasma phagocytophilum and Babesia spp. in Ixodes ricinus ticks from urban and rural environment, northern Poland, by real-time polymerase chain reaction. Exp Appl Acarol 66:63-81. https:// doi.org/10.1007/s10493-015-9887-2

Stańczak J, Biernat B, Racewicz M, Zalewska M, Matyjasek A (2018) Prevalence of different Rickettsia spp. in Ixodesricinus and Dermacentor reticulatus ticks (Acari: Ixodidae) in north-eastern Poland. Ticks Tick Borne Dis 9:427-434. https://doi.org/10.1016/j.ttbdis.2017.12.010

Tołkacz K, Bednarska M, Alsarraf M, Dwużnik D, Grzybek M, Welc-Faleciak R, Behnke JM, Bajer A (2017) Prevalence, genetic identity and vertical transmission of Babesia microti in three naturally infected species of vole, Microtus spp. (Cricetidae). Parasit Vectors 10:66. https://doi.org/10.1186/ s13071-017-2007-X

Welc-Falęciak R, Bajer A, Behnke JM, Siński E (2008) Effects of host diversity and the community composition of ixodid ticks (Ixodidae) on Babesia microti infection. Int J Med Microbiol 298:235242. https://doi.org/10.1016/j.ijmm.2007.12.002

Wodecka B, Rymaszewska A, Skotarczak B (2014) Host and pathogen DNA identification in blood meals of nymphal Ixodes ricinus ticks from forest parks and rural forests of Poland. Exp Appl Acarol 62:543-555. https://doi.org/10.1007/s10493-013-9763-X

Wójcik-Fatla A, Zając V, Sawczyn A, Sroka J, Cisak E, Dutkiewicz J (2016) Infections and mixed infections with the selected species of Borrelia burgdorferi sensu lato complex in Ixodes ricinus ticks collected in eastern Poland: a significant increase in the course of 5 years. Exp Appl Acarol 68:197-212. https://doi.org/10.1007/s10493-015-9990-4

Zając V, Wójcik-Fatla A, Sawczyn A, Cisak E, Sroka J, Kloc A, Zając Z, Buczek A, Dutkiewicz J, Bartosik K (2017) Prevalence of infections and co-infections with 6 pathogens in Dermacentor reticulatus ticks collected in eastern Poland. Ann Agric Environ Med 24:26-32. https://doi. org/10.5604/12321966.1233893

Zygner W, Wedrychowicz H (2006) Occurrence of hard ticks in dogs from Warsaw area. Ann Agric Environ Med 13:355-359

Publisher's Note Springer Nature remains neutral with regard to jurisdictional claims in published maps and institutional affiliations. 